\title{
UJI EFEKTIVITAS EKSTRAK ETANOL DAUN LIDAH MERTUA (Sansevieria trifasciata Prain) TERHADAP KHAMIR Candida albicans
}

\author{
Oom Komala ${ }^{1)}$, Ike Yulia ${ }^{2)}$ dan Rita Pebrianti ${ }^{3)}$ \\ 1) Program Studi Biologi, ${ }^{2,3)}$ Program Studi Farmasi, \\ FMIPA Universitas Pakuan, Bogor
}

\begin{abstract}
ABSTRAK
Lidah mertua (Sansevieria trifasciata Prain) merupakan tanaman yang berasal dari Afrika dan dikenal sebagai antimikroba, serta berkhasiat obat. Tujuan dari penelitian ini ialah mengetahui kandungan antimikroba ekstrak daun lidah mertua dengan menentukan lebar daerah hambat (LDH) terhadap khamir Candida albicans menggunakan metode difusi kertas cakram. Pengujian LDH dilakukan terhadap konsentrasi ekstrak daun lidah mertua $60 \%, 70 \%, 80 \%, 90 \%$, serta ketokonazol 14 ppm sebagai kontrol positif dan karboksi metil selulosa (CMC) 0,5\% sebagai kontrol negatif. Hasil penelitian menunjukkan bahwa ekstrak daun lidah mertua pada konsentrasi $90 \%$ membentuk zona hambat terhadap $C$. albicans yang paling luas tetapi tidak jernih. Hasil analisis mutu ekstrak diketahui bahwa kadar abu ekstrak daun lidah mertua yang tidak larut dalam asam ialah $0,23 \%$ dan yang larut dalam air ialah 5,04\%. Sedangkan hasil penetapan kadar sari ekstrak daun lidah mertua yang larut dalam air ialah $38,76 \%$ dan yang larut dalam etanol ialah $12,53 \%$. Hasil fitokimia diketahui ekstrak daun lidah mertua mengandung saponin, flavonoid, steroid, dan triterpenoid, yang berfungsi dapat menghambat $C$. albicans.
\end{abstract}

Kata kunci : daun lidah mertua (Sansevieria trifasciata Prain), Candida albicans, efektivitas, antikhamir

\section{ABSTRACT}

Sansevieria trifasciata Prain is original plant from tropical Africans continent and known as an anti-microbial agent, and medicinal plants. The purpose of this study was to know the anti-microbial compound that contained in the leaves extract of $S$. trifasciata and to determine the inhibitor width area against the Candida albicans yeast by using diffusion method. Inhibitor width area tests carried out on leaves extract concentration of $S$. trifasciata Prain i.e 60\%, $70 \%, 80 \%, 90 \%$, ketokonazol $14 \mathrm{ppm}$ as a positive control, and Carboxy Methyl Cellulose (CMC) $0,5 \%$ as a negative control. The result showed that leaves extract of the $S$. trifasciata could inhibit the growth of $C$. albicans partially. The concentration $90 \%$ formed the partial highess inhibition zone. The result analysis of quality showed that ash measurement leaf extract non soluble acid is $0.23 \%$ and waterbase soluble is $5.04 \%$. Pollen extract concentration measurement waterbase is $38.76 \%$, ethanol base is $12.53 \%$. Phytochemical analysis shown saponins, flavonoids, steroids, triterpenoids compound as antiCandida albicans.

Keyword : Sansevieria trifasciata Prain, Candida albicans, the effectivenes test, anti-yeast

\section{PENDAHULUAN}

Seiring dengan perkembangan zaman, pemakaian obat tradisional di Indonesia mengalami kemajuan yang sangat pesat. Saat ini obat-obatan tradisional menjadi salah satu alternatif pengobatan, di samping obat-obat sintetik yang sudah banyak beredar di pasaran. Hal ini disebabkan obat tradisional relatif lebih murah, selain itu lebih aman digunakan. Demikian pula beberapa jenis obat tradisional tidak kalah jika 
dibandingkan dengan obat-obat sintetik. Menyadari pentingnya obat tradisional untuk meningkatkan kesehatan masyarakat, maka tanaman sebagai bahan baku obat tradisional perlu dimanfaatkan sebaik-baiknya. Kecenderungan kembali ke alam (Back to nature) sangat menguntungkan bagi negara kita karena begitu banyaknya tumbuhan obat yang kita miliki, salah satunya adalah dari tanaman lidah mertua keluarga Liliaceae yang menambah khazanah kekayaan tanaman obat.

Sansevieria trifasciata yang dikenal masyarakat sebagai tanaman lidah mertua merupakan salah satu tanaman berkhasiat obat di Indonesia. Secara tradisional tanaman yang berasal dari Benua Afrika tropis ini sering dipakai sebagai antimikroba dan antibiotik (Yoshihiro, 1997). Khasiat tanaman lidah mertua dalam menyembuhkan berbagai macam penyakit juga diduga berhubungan dengan kandungan senyawa kimia yang dikandungnya antara lain daun dan rimpang lidah mertua mengandung saponin dan kardenolin, di samping itu daunnya juga mengandung flavonoid, tanin dan polifenol (Depkes RI, 1997). Senyawa yang diduga memiliki aktivitas antimikroba pada daun lidah mertua adalah tanin, flavonoid dan saponin. Tanin dan flavonoid merupakan turunan polifenol. Mekanisme kerja turunan fenol adalah dengan mendenaturasidan mengkoagulasi protein sel mikroba (Siswandono dan Soekardjo, 1995). Aktifitas antimikroba dari saponin disebabkan sifatnya yang memiliki gugus polar (gula) dan non polar (terpenoid) sehingga dapat menurunkan tegangan permukaan dinding sel mikroba dan mengganggu permeabilitas sel bakteri (Jawetz dkk., 1996).

Candida albicans selalu ditemukan di dalam saluran pencernaan manusia dan hewan, sehingga kandidiasis selalu dianggap sebagai penyakit endogen. Kandidiasis pada manusia lebih banyak diderita oleh anak-anak dalam bentuk sariawan rongga mulut, wanita pada alat kelaminnya dalam bentuk keputihan dan menyerang kuku. Obat sintetik untuk penyakit yang disebabkan oleh $C$. albicans relatif cukup mahal, banyak yang resistensi dan tidak dapat menghambat khamir yang bersifat sistemik, sehingga perlu diteliti senyawa antikhamir yang berasal dari bahan alam, seperti tanaman lidah mertua (Nasution, 2005).

Tanaman Sansevieria tergolong dalam tanaman obat karena kandungan kimia dari daun, buah dan akar telah teruji positif efek farmakologisnya (Depkes RI, 1997). Dalam penelitian ini akan dilakukan pengujian aktivitas ekstrak etanol daun lidah mertua terhadap khamir $C$. albicans sehingga diharapkan nantinya ekstrak daun lidah mertua menjadi pengobatan alternatif serangan khamir Candida albicans.

\section{BAHAN DAN METODE}

Simplisia daun lidah mertua segar varietas Laurentii (N.E.Br) De Wild, yang tepi daunnya berwarna kuning emas dengan ujung daun runcing dibersihkan dari kotoran dengan menggunakan air bersih yang mengalir. Simplisia dirajang kemudian dikeringkan di dalam oven pada suhu $45^{\circ} \mathrm{C}$ selama dua hari atau sampai kering. Setelah kering ditumbuk menjadi serbuk halus dengan menggunakan grinder dan diayak dengan pengayak no. 20, kemudian ditimbang, dan disimpan dalam wadah bersih dan tertutup rapat. Kadar air ditetapkan dengan alat Moisture Balance AND MX50. Persyaratan kadar air daun yaitu $\leq$ 5\% (DepKes RI, 1985).

Serbuk daun lidah mertua diekstrak dengan cara maserasi menggunakan pelarut etanol $70 \%$. dengan perbandingan 1:10. Sebanyak $1 \mathrm{Kg}$ serbuk dimasukkan kedalam maserator, lalu direndam dengan $10 \mathrm{~L}$ etanol $70 \%$ (v/v). Kemudian diaduk dan direndam selama 24 jam lalu disaring 
dengan kain batis. Maserat di enap tuangkan, residu dimaserasi kembali dengan jenis dan jumlah pelarut yang sama sebanyak 2 kali pengulangan. Hasil saringan atau filtrat etanol dicampur dan diuapkan menggunakan rotavapor sampai tidak keluar lagi pelarutnya. Ekstrak kental dipekatkan di atas waterbath dan dikemas dalam botol berwarna coklat.

Setelah diperoleh ekstrak kental daun lidah mertua dilakukan hasil analisis mutu ekstrak yang meliputi penentuan kadar abu yang tidak larut dalam asam, kadar abu yang larut dalam air, kadar sari yang larut dalam air dan kadar sari yang larut dalam etanol (Depkes RI, 1985).

Identifikasi kandungan zat pada ekstrak daun lidah mertua dilakukan dengan uji fitokimia yang meliputi uji flavonoid (DepKes RI, 1995), uji tanin (pereaksi besi aluminium klorida dan gelatin), uji saponin (DepKes RI, 1977), uji alkaloid (menggunakan pereaksi Mayer dan Bouchaedat), uji steroid, uji triterpenoid (Uji Lieberman-Buchard), dan uji glikosida (Uji LiebermanBuchard).

Untuk menguji efektivitas ekstrak kental daun lidah mertua terhadap isolat khamir $C$. albicans menggunakan metode difusi kertas cakram (Sa'diah, 2004). Media potato dextrose ditanami khamir C. albicans $1 \mathrm{ml}$ konsentrasi pengenceran $10^{-6}$. Untuk ekstrak daun $S$. trifasciata yang duji pada konsentrasi $30 \%, 40 \%, 50 \%, 60 \%$ dan $70 \%$ (pada uji pendahuluan) dan 60\%, 70\%, $80 \%$ dan $90 \%$ (pada uji lanjut). Cakram kertas dibuat dari kertas saring Whatman diameter $6 \mathrm{~mm}$, dicelupkan ke dalam sediaan uji $( \pm 1 \mathrm{jam})$, dikeringkan $37^{\circ} \mathrm{C}$ $( \pm 1$ jam). Selanjutnya kertas cakram direndam dalam larutan selama 24 jam pada suhu $37^{\circ} \mathrm{C}$ kemudian keringkan (Komala $d k k$., 2012). Larutan kontrol positif digunakan ketokonazol 14 ppm, untuk kontrol negatif digunakan karboksi metil selulosa (CMC) $0,5 \%$ Setelah khamir tersebar secara merata menggunakan lidi kapas steril, selanjutnya diletakkan kertas cakram yang mengandung ekstrak uji, ketakonazol, dan air. Biakan uji diinkubasi selama 24 jam pada suhu $37^{\circ} \mathrm{C}$ dan diukur lebar daerah hambat (LDH) masing-masing cakram uji terhadap pertumbuhan khamir C.Albicans (Sa'diah, 2004).

\section{HASIL DAN PEMBAHASAN Analisis Karakteristik Simplisia}

Serbuk daun lidah mertua yang diperoleh adalah sebesar $1,5 \mathrm{Kg}$ dari 15 $\mathrm{Kg}$ daun lidah mertua basah. Berdasarkan hasil analisis kadar air simplisia daun lidah mertua adalah $8,045 \%$. Hal ini menunjukkan bahwa kadar air serbuk daun lidah mertua tidak memenuhi persyaratan kadar air daun yaitu $\leq 5 \%$ (Depkes RI, 1985). Kadar air yang tinggi mengakibatkan bakteri dan kapang mudah untuk berkembang biak (Wijayakusuma $d k k .$, 1992), Sehingga simplisia harus segera diekstraksi.

\section{Ekstrak Kental Daun Lidah Mertua}

Hasil maserasi dari $900 \mathrm{~g}$ serbuk diperoleh ekstrak kental sebanyak 73,6 gram. Nilai rendemen sebesar $8,18 \%$. Nilai tersebut menunjukkan bahwa ekstrak yang dihasilkan tidak terlalu banyak karena daun lidah mertua mengandung kadar air dan serat yang sangat tinggi.

\section{Hasil Penetapan Kadar Abu dan Kadar Sari Ekstrak}

Hasil penetapan kadar abu daun lidah mertua ialah $13,53 \%$. Nilai kadar abu pada serbuk daun lidah mertua termasuk tinggi karenakemungkinan mengandung senyawa anorganik dan mineral yang sangat tinggi yang 
disebabkan oleh pemanasan yang tidak sempurna (Depkes RI, 1995).

Berdasarkan penelitian diketahui bahwa kadar abu ekstrak daun lidah mertua yang tidak larut dalam asam ialah $0,23 \%$ dan kadar abu ekstrak daun lidah mertua yang larut dalam air ialah 5,04\%. Kadar abu yang tidak larut dalam asam adalah bagian abu yang tidak bisa dilarutkan dalam asam keras, bagian yang tidak larut itu disebut silikat atau pasir. Hasil yang ditunjukkan sebanyak 0,23\% yang tidak larut atau diduga mengandung silikat. Kadar abu yang larut dalam air adalah bagian abu yang dapat larut dalam air, Hasil yang ditunjukkan sebesar $5,04 \%$ adalah oksida-oksida yang dapat larut dalam air (Depkes RI, 1995).

Hasil penetapan kadar sari ekstrak daun lidah mertua yang larut dalam air ialah 38,76\% dan kadar sari daun lidah mertua yang larut dalam etanol ialah $12,53 \%$. Hal ini menunjukkan bahwa senyawa yang terdapat dalam ekstrak daun lidah mertua bersifat polar dan dapat berpengaruh terhadap pertumbuhan mikrob.

\section{Hasil Uji Fitokimia Ekstrak Daun Lidah Mertua}

Ekstrak daun lidah mertua mengandung senyawa saponin, flavonoid, steroid dan triterpenoid yang ditunjukkan dengan hasil positif. Hasil ini sesuai dengan peneliti Yoshihiro et al. (1997), bahwa Sansevieria mengandung saponin dan steroid. Demikian pula menurut Sastradipraja (1997), kandungan lidah mertua antara lain polifenol dan saponin.

Flavonoid adalah suatu kelompok senyawa fenol yang terbanyak terdapat di alam. Aktifitas biologis senyawa flavonoid terhadap khamir $C$. albicans dilakukan dengan merusak dinding sel dan senyawa tersebut dapat masuk ke dalam inti sel khamir. Menurut Sa'diah (2004) bahwa senyawa flavonoid memiliki aktivitas yang tinggi terhadap khamir C. albicans. Golongan flavonoid ini diduga senyawa turunan 5,4'dihidroksi flavon.

Senyawa steroid merupakan suatu golongan senyawa triterpenoid yang mengandung inti siklopentana perhidrofenantren yaitu dari tiga cincin sikloheksana dan satu cincin siklopentana. Triterpenoid adalah senyawa yang kerangka karbonnya berasal dari enam satuan isoprena dan secara biosintesis diturunkan dari hidrokarbon C-30 asiklik, yaitu skualena, senyawa ini tidak berwarna, berbentuk kristal, bertitik leleh tinggi dan bersifat optis aktif. Kemampuan senyawa steroid dan triterpenoid sebagai antikhamir Candida albicans sangat dipengaruhi oleh keaktifan biologis senyawa tersebut. Keaktifan biologis dari senyawa ini disebabkan oleh adanya gugus karbon. Adanya gugus karbon ini apabila mengalami kontak dengan khamir $C$. albicans akan bereaksi dengan senyawasenyawa asam yang menyusun dinding sel bakteri/jamur (Robinson, 1991).

Senyawa saponin mempunyai sifat seperti sabun yang merupakan senyawa "surfactan agent" yang kuat, sehingga dapat menurunkan tegangan permukaan sel (Robinson,1991).

Diabsorpsinya saponin pada permukaan sel akan mengakibatkan kerusakan dengan naiknya permeabilitas atau kebocoran membran sel, sehingga bahanbahan essensial yang dibutuhkan oleh bakteri/jamur untuk kehidupannya hilang dan dapat menyebabkan kematian sel bakteri/jamur (Robinson, 1991).

\section{Hasil Uji Pendahuluan Terhadap $C$. albicans}

Berdasarkan hasil uji pendahuluan (Tabel 1), ekstrak daun lidah mertua mampu membentuk lebar daerah hambat yang besar pada konsentrasi $70 \%$. 
Tabel 1. Rata-rata LDH (mm) Ekstrak Daun Lidah Mertua Terhadap Candida albicans

\begin{tabular}{|c|r|r|r|r|r|c|}
\hline \multirow{3}{*}{ ulangan } & \multicolumn{5}{|c|}{ LDH (mm) } & \multirow{2}{*}{ Ketonazol 14 ppm } \\
\cline { 2 - 6 } & $30 \%$ & $40 \%$ & $50 \%$ & $60 \%$ & $70 \%$ & \\
\hline Rata & $11 \pm 1$ & 12,6 & 14,3 & 17,6 & 22,3 & $26 \pm 1$ \\
rata & & $\pm 0,58$ & $\pm 0,58$ & $\pm 0,58$ & \pm 8 & \\
& & & & & & \\
\hline
\end{tabular}

Pada setiap konsentrasi ekstrak daun lidah mertua membentuk zona parsial (tidak absolut) atau tidak mematikan khamir 100\% karena masih ada pertumbuhan pada daerah hambat yang terbentuk. Kontrol positif ketokonazol $14 \mathrm{ppm}$ membentuk lebar daerah hambat yang paling besar dalam menghambat pertumbuhan Candida albicans.

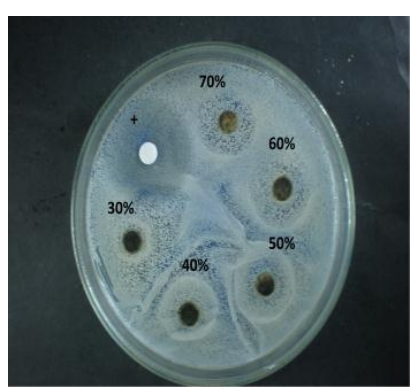

Gambar 1. Lebar Daerah Hambat Ekstrak Daun Lidah Mertua pada Uji Pendahuluan Terhadap Khamir Candida albicans dengan konsentrasi $30 \%$ sampai $70 \%$

\section{Hasil Uji Antikhamir Ekstrak Etanol Daun Lidah Mertua}

Berdasarkan hasil dari uji pendahuluan (Gambar 1) maka dilakukan uji lanjut dengan variasi konsentrasi $60 \%$, $70 \%$, 80\%, dan $90 \%$ untuk mengetahui konsentrasi yang paling baik dalam menghambat pertumbuhan khamir $C$. albicans.
Pada uji lanjut hasilnya (Tabel 2, Gambar 2) menunjukkan adanya aktivitas antikhamir dari ekstrak daun lidah mertua pada konsentrasi 90\% dengan lebar daerah hambat yang paling besar. Menurut Gholib (2009) senyawa alkaloid, saponin, flavonoid dan steroid dari ekstrak tumbuhan daun senggani (Melastomma malabathricum L.) berkhasiat antijamur C.albicans. Diketahui juga bahwa $C$. albicans lebih tahan dibanding kapang $T$. mentagrophytes.

Pada ekstrak daun lidah mertua juga mengandung senyawa saponin, flavonoid, steroid dan triterpenoid, yang menunjukkan khasiat sebagai antikhamir tersebut.

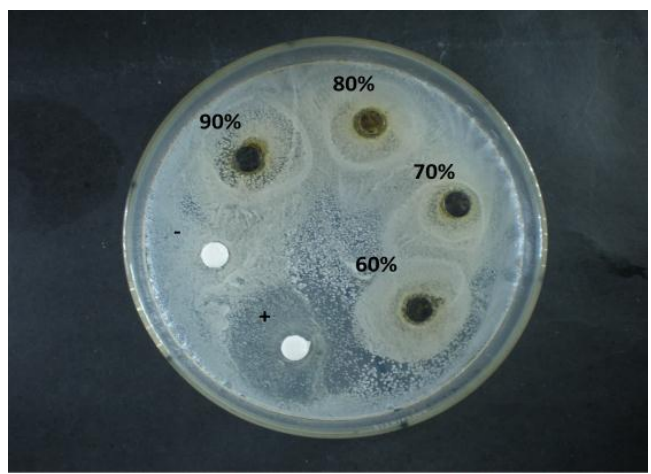

Gambar 2. Lebar Daerah Hambat Ekstrak Daun Lidah Mertua pada Uji Lanjut Terhadap Khamir Candida albicans 
Tabel 2. Rata-rata LDH (mm) Ekstrak Daun Lidah Mertua Pada Uji Lanjut

\begin{tabular}{|c|c|c|c|c|c|c|}
\hline \multirow[t]{2}{*}{ Ulangan } & \multicolumn{4}{|c|}{$\begin{array}{c}\text { LDH (mm) } \\
\text { Ekstrak Daun Lidah Mertua }\end{array}$} & $\begin{array}{l}\text { Kontrol } \\
\text { Positif }\end{array}$ & $\begin{array}{l}\text { Kontrol } \\
\text { Negatif }\end{array}$ \\
\hline & $60 \%$ & $70 \%$ & $80 \%$ & $90 \%$ & & \\
\hline 1 & 9 & 13 & 15 & 23 & 30 & 0 \\
\hline 2 & 8 & 12 & 14 & 20 & 28 & 0 \\
\hline 3 & 8 & 11 & 13 & 20 & 28 & 0 \\
\hline $\begin{array}{l}\text { Rata- } \\
\text { rata }\end{array}$ & 8,3 & 12 & 14 & 21 & 28,6 & 0 \\
\hline
\end{tabular}

Rata-rata LDH pada Tabel 2 lebih kecil dari pada Tabel 1, kemungkinan bakteri pada Tabel 2 lebih subur sehingga daya hambat baik ekstrak maupun ketokenazol lebih kecil. Berdasarkan sidik ragam Rancangan Acak Lengkap (RAL) dan Tabel ANOVA menunjukkan bahwa konsentrasi 90\% daun lidah mertua memberikan pengaruh yang berbeda terhadap khamir $C$. aldicans. Pada konsentrasi $90 \%$ menunjukkan nilai LDH $21 \mathrm{~mm}$, sedangkan untuk nilai LDH terendah ditunjukkan oleh ekstrak daun lidah mertua pada konsentrasi $60 \%$ dengan nilai $\mathrm{LDH}$ yaitu $8,33 \mathrm{~mm}$. Dari hasil yang didapatkan maka nilai $\mathrm{LDH}$ dari ekstrak daun lidah mertua pada konsentrasi $90 \%$ lebih rendah dari nilai LDH kontrol positif yang memiliki nilai LDH 28,67 mm. Hal ini dapat terjadi karena dosis (konsentrasi) ekstrak daun lidah mertua yang dipakai pada penelitian ini masih relatif rendah ialah $90 \mathrm{~g}$ dilarutkan dalam $100 \mathrm{ml}$ untuk konsentrasi 90\%, sehingga harus di tingkatkan dosis nya agar dapat memberikan efek yang lebih baik bila dibandingkan dengan kontrol positif, selain itu untuk meningkatkan kemampuannya dalam menghambat pertumbuhan khamir C. albicans. Akan tetapi dalam menaikkan dosis (konsentrasi) ekstrak daun lidah mertua perlu kita perhatikan pula efek toksisitas dari daun lidah mertua, yang perlu dilakukan penelitian. Ketokonazol dipilih sebagai kontrol positif pada penelitian ini karena memiliki aktivitas antimikotik terhadap ragi dermatofit. Bekerja dengan menghambat sitokrom $\mathrm{P} 450$ jamur, dengan mengganggu sintesis ergosterol yang merupakan komponen penting dari membran sel jamur. Sebagai turunan Imidazol (Alcamo,1991), Ketokonazol mempu-nyai aktivitas anti jamur baik sistemik maupun nonsistemik. Efektif terhadap Candida, Cocciodes immitis, Cryptococcus neoformans, $H$. Capsulatum, B. Dermatitidis, Aspergillus dan sporothrix spp.

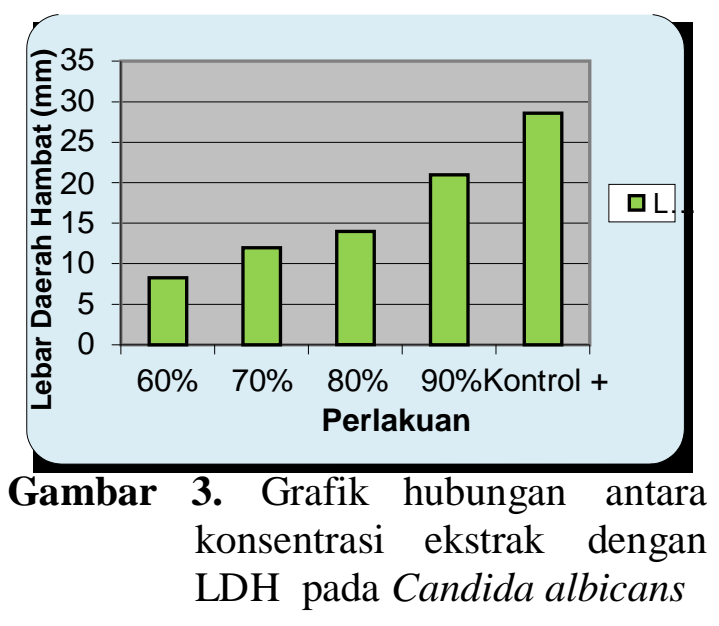

Dari grafik pengukuran LDH terlihat bahwa makin besar konsentrasi ekstrak daun lidah mertua semakin luas lebar daerah hambat (LDH) yang dihasilkan dan bersifat parsial (Gambar $3)$.

\section{KESIMPULAN DAN SARAN}

\section{Kesimpulan}

1. Ekstrak daun lidah mertua (Sansevieria trifasciata Prain) dapat menghambat pertumbuhan Candida albicans tetapi tidak jernih. Konsentrasi ekstrak daun lidah mertua $90 \%$ membentuk zona hambat yang paling luas. Semakin tinggi konsentrasi ekstrak maka semakin besar aktivitas hambatannya. 
2. Ekstrak daun lidah mertua berdasarkan uji fitokimia menunjukkan adanya senyawa saponin, flavonoid, steroid, dan triterpenoid yang bersifat sebagai anti Candida albicans.

\section{Saran}

Perlu dilakukan uji toksisitas dari ekstrak daun lidah mertua serta dibuat formulanya untuk mencegah atau mengurangi penyakit yang disebabkan oleh khamir Candida albicans.

\section{DAFTAR PUSTAKA}

Alcamo, I.E. 1991. Fundamental of Mic robiology. Third edition. The Benjamin/Cumminompany,

Publishing Company, Inc.777782.

Departemen Kesehatan RI. 1997. Inventaris Tanaman Obat Indonesia (IV). Badan Penelitian Dan Pengembangan Kesehatan. Jakarta.

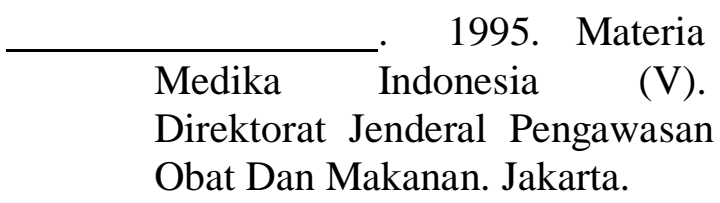

Depkes RI. 1985. Cara Pembuatan Simplisia. Departemen Kesehatan RI. Jakarta.

Gholib, Djaenudin. 2009. Uji Daya Hambat Daun Senggani (Melastoma malabathricum L.)
Terhadap Trichophyton mentagrophytees Dan Candida albicans. Berita Biologi. 9(5) : 523-527.

Jawetz., E., Joseph. M., dan Edward. A. 1996. Mikrobiologi Kedokteran, Edisi 20. Alih bahasa : dr. Edi Nugroho dan dr. R. F. Maulany. EGC, Jakarta.

Komala, O., Bina L.S., Nina S. 2012. Uji Efektivitas Ekstrak Etanol Buah Pare (Momordica charantia L) sebagai antibakteri Salmonella typhi. Fitofarmaka, Vol 2 No. 1 :101-106.

Nasution. 2005. Medical Mycology Message From Dermatologie. Los Altos. California.

Sa'diah, Siti. 2004. Pemeriksaan Flavonoid Dan Asam Fenolat Ekstrak Etanol Dan Fraksi Herba Samboloto (Andrographis paniculata Ness, Acanthaceae) Serta Uji Aktivitas Antibakteri Dan Antifungi. Ekologia. Vol 4 No 2 :47-51.

Sastradipraja, S. 1997. Tanaman Hias, Bogor : Lembaga Biologi Nasional LIPI.

Siswandono dan Soekardjo. B. 1995. Kimia Medisinal. Airlangga Press. 